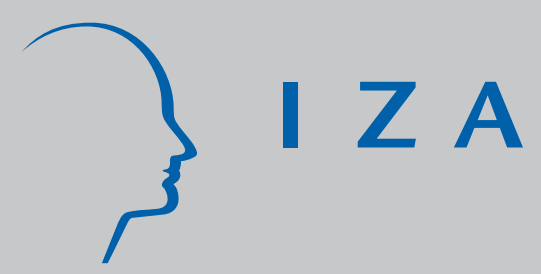

IZA DP No. 112

Innovations, Wages and Demand for Heterogeneous Labour: New Evidence from a Matched Employer-Employee Data-Set

Lutz Bellmann

Thorsten Schank

February 2000 


\title{
Innovations, Wages and Demand for Heterogeneous Labour: New Evidence from a Matched Employer-Employee Data-Set
}

\author{
Lutz Bellmann \\ Institut für Arbeitsmarkt- und Berufsforschung, Bundesanstalt für Arbeit and IZA, Bonn \\ Thorsten Schank \\ Institut für Arbeitsmarkt- und Berufsforschung, Bundesanstalt für Arbeit
}

\author{
Discussion Paper No. 112 \\ February 2000
}

\author{
IZA \\ P.O. Box 7240 \\ D-53072 Bonn \\ Germany \\ Tel.: +49-228-3894-0 \\ Fax: +49-228-3894-210 \\ Email: iza@iza.org
}

This Discussion Paper is issued within the framework of IZA's research area The Future of Work. Any opinions expressed here are those of the author(s) and not those of the institute. Research disseminated by IZA may include views on policy, but the institute itself takes no institutional policy positions.

The Institute for the Study of Labor (IZA) in Bonn is a local and virtual international research center and a place of communication between science, politics and business. IZA is an independent, nonprofit limited liability company (Gesellschaft mit beschränkter Haftung) supported by the Deutsche Post AG. The center is associated with the University of Bonn and offers a stimulating research environment through its research networks, research support, and visitors and doctoral programs. IZA engages in (i) original and internationally competitive research in all fields of labor economics, (ii) development of policy concepts, and (iii) dissemination of research results and concepts to the interested public. The current research program deals with (1) mobility and flexibility of labor markets, (2) internationalization of labor markets and European integration, (3) the welfare state and labor markets, (4) labor markets in transition, (5) the future of work, (6) project evaluation and (7) general labor economics.

IZA Discussion Papers often represent preliminary work and are circulated to encourage discussion. Citation of such a paper should account for its provisional character. 


\section{ABSTRACT \\ Innovations, Wages and Demand for Heterogeneous Labour: New Evidence from a Matched Employer-Employee Data-Set}

This paper examines the impact of innovations and wages on the demand for heterogeneous labour. Based on matched data from the IAB-establishment panel survey and the files of the employment statistics register for the year 1995, input shares derived from a generalised Leontief cost function are estimated for six qualification groups (blue and white collar workers stratified into unskilled, skilled and highly-skilled employees) in the West German production industries.

With the exception of highly skilled blue collar workers, innovations have a positive and significant effect on labour demand for all groups, with an estimated relative change of the conditional labour demand ranging between $3.2 \%$ and $6.3 \%$. Between white collar workers as well as between unskilled and skilled blue collar workers, we find an increasing positive impact of innovations on labour demand with qualification level. Skilled and highly skilled employees are found to be substitutes for the unskilled. This result implies that more flexible wages of the unskilled would reduce the unemployment of this group. Finally, our data is not consistent with separability of blue-collar employees from white collar employees, there is weak evidence that skilled and highly skilled blue collar employees can be aggregated.

JEL Classification: C31, J23, J31, D21, O31

Keywords: Demand for labor, labor costs, substitution, firm behavior, innovation

Lutz Bellmann

Institut für Arbeitsmarkt- und Berufsforschung

der Bundesanstalt für Arbeit

Regensburger Str. 104

90327 Nürnberg

Tel.: +49-911-179-3046

Fax: +49-911-179-3297

Email: lutz.bellmann@iab.de 


\section{Introduction}

The dramatic rise of unemployment in Germany within the last two decades did not emerge uniformly across the workforce. Unemployment rates of university graduates, skilled workers and qualified white collar workers are not only lower than those of unskilled and semi-skilled employees, also did this gap widen in the 90s. Reinberg and Rauch (1999) calculated for the former West Germany in 1997, that almost $25 \%$ of the labour force without vocational qualification had been without a job, whereas the unemployment rates were much lower for university graduates $(4.1 \%)$, graduates from a post-secondary technical college $(2.8 \%)$, graduates from a technical college $(3.9 \%)$ as well as for employees with a completed vocational training (7.4\%). This development is often attributed to technical change and non-flexible wages of the unskilled. Therefore, our study focuses on

(i) the impact of product and process innovations -the two major components of technological change- on the demand for heterogeneous labour and

(ii) the substitution possibilities between different skill groups

Whether technical progress has a labour-saving or labour-augmenting effect is theoretically ambiguous. In this context, two forms of technical progress are normally distinguished: process and product innovations.

Process innovations define the implementation of new or modified production systems, thereby rising the productivity of labour and/or capital. Hence, the same amount of output could be produced by less labour, for which reason process innovations are typically associated with a reduction in labour demand. However, this neglects a possible scale effect. Since marginal production costs have been decreased, the firm can lower its product prices and therefore achieve a higher product demand (given a positive price elasticity of product demand).

Product innovations refer to the introduction of new products, which are novel for the whole market or just newly included into the supply variety of the firm. In general, this should induce a rise in output and labour demand. If the new products are only substitutes for existing ones, the employment increase may be moderate (see Blechinger et al., 1994). 
The scale effect of both types of innovations on labour demand depends on the behaviour of the firm's competitors on its product market and on the market structure. If competing firms innovate themselves, e.g. they are able to produce at lower costs or supply new products, the rise in output should be smaller or even negative. Since prices are less flexible, employment effects of innovations are expected to be lower in monopolistic or oligopolistic markets than under perfect competition. Finally, as Smolny and Schneeweis (1999) pointed out, a possible complementarity between innovations and investments might induce a substitution of capital for labour. They argue that new products, for example, would require the investment in new capital.

Since economic theory provides ambiguous predictions on the employment effects of innovations, the issue has to be addressed empirically. For Germany, only a few studies at the firm level exist, which tend to confirm that positive employment effects arise more likely from product innovations than from process innovations ${ }^{1}$.

Due to data limitations, almost all of the existing German studies included only one labour input. It may be of particular interest, however, to examine the effects of innovations on different skill groups. This could detect, whether technical progress in form of innovations is partly responsible a the shift in labour demand in favour of skilled employees. At least for process innovations, one might expect that a labour-saving effect of innovations is the highest for the unskilled or that labour-augmenting scale-effects following innovations favour skilled workers.

Studies from several other countries (for an overview see Fitzenberger and Franz 1998), claim that inflexible wages would be responsible for the increased unemployment of unqualified workers. They argue that a lower demand for this skill group would arise from technical progress and would require a fall in the relative wage of the unqualified to push their demand again. Whether relative wages affect the labour demand, depends on the substitutional relationships between different skill groups, implied by the production technology. ${ }^{2}$

\footnotetext{
${ }^{1}$ See for example Zimmermann (1989), König/Buscher/Licht (1995), Blechinger/Pfeiffer (1998), Rottmann/Ruschinski (1998), Flaig/Rottmann (1998), Smolny (1999).

${ }^{2}$ For a summary of German studies of wage elasticities of labour demand for different skill groups see Riphan/Zimmermann (1999).
} 
We will investigate the impact of innovations and wages on heterogeneous labour demand using a new employer-employee data-set for Germany. Based on matched data from the IAB-establishment panel survey and the historic files of the employment statistics register, employees have been classified into six qualification groups (blue and white collar workers stratified into unskilled, skilled and highly skilled employees). A conditional labour demand system derived from a generalised Leontief cost function is estimated with cross-sectional data of 1995 for the manufacturing and the construction industry of West Germany.

The paper proceeds as follows. Section 2 outlines the theoretical framework. Section 3 deals with the empirical specification. Section 4 describes the used employer-employee data-set. The estimation results are presented and discussed in section 5 . Concluding remarks are given in section 6 . 


\section{Theoretical Framework}

Given that certain regularity conditions are satisfied, cost and production functions contain the same information; both can be used to estimate labour demand elasticities. The decision between them depends on whether output, input prices and input quantities are considered as endogenous or exogenous (respectively). Since a cross-sectional data-set is used in this paper, the assumption of fixed input prices (i.e. wages) and an exogenous output can be justified. Therefore, we use a cost function to describe the production technology, where capital as well as innovations are treated as fixed in the short run.

The labour input is subdivided into six categories (blue and white collar workers stratified into unskilled, skilled and highly skilled employees). Thus, the variable production costs $C$ (i.e. the wage costs), which are necessary to produce a certain output level, $Y$, with a given capital stock, $K$, and for a given product $(P D)$ and process quality $(P Z)$, are given by:

$C=f\left(w_{1}, w_{2}, w_{3}, w_{4}, w_{5}, w_{6}, Y, K, P D, P Z\right)$

where $w_{i}$ denotes the wage of labour group i. Applying Shepard's Lemma -i.e. $\partial C / \partial w_{i}=N_{i}$ - yields the conditional labour demand function

$N_{i}=g\left(w_{1}, w_{2}, w_{3}, w_{4}, w_{5}, w_{6}, Y, K, P D, P Z\right)$.

Since a cost function is concave in prices $\left(\partial^{2} C / \partial w_{i} \leq 0\right)$, therefore the own wage has a non-positive impact on the demand for each skill group $\left(\partial N_{i} / \partial w_{i}=\partial^{2} C / \partial w_{i} \leq 0\right)$. The sign of the cross-wage elasticities is unclear $\left(\partial N_{i} / \partial w_{j}<>0, \quad \mathrm{i} \neq \mathrm{j}\right)$. However, for each labour input, at least one cross-wage elasticity has to be positive. The cost function is linear homogeneous in wages, thus the conditional labour demand functions are homogeneous of degree zero in wages, i.e. demand for heterogeneous labour remains unaffected if all wages experience the same relative change. A negative own-wage elasticity requires each skill group to be a substitute to at least one other group 
$\left(\partial N_{i} / \partial w_{j}>0, \quad \mathrm{i} \neq \mathrm{j}\right)$. While the output effect on labour demand is definitely nonnegative $\left(\partial N_{i} / \partial Y \geq 0\right)$, the impact of process and product innovations is undetermined $\left(\partial N_{i} / \partial P D<>0, \partial N_{i} / \partial P D<>0\right)$. Technical progress (in form of product and process innovations) is expected to have diverse effects on different skill groups. At least after the implementation of process innovations, the proportion of highly skilled and skilled workers should rise. Bartel and Lichtenberg (1987), for example, have argued on the basis of the learning curve hypothesis that highly educated workers have a comparative advantage with respect to the adjustment to and implementation of new technologies.

For instance, if technical progress increases the demand for the skilled employees and reduces the demand for the unskilled, flexible wages of unskilled workers are required to compensate for the downfall in demand for this group. Given a negative own-wage elasticity of the unqualified employees, lowering their wages could prevent a rise in unemployment of this group. This result, however, depends on the magnitude of their own-wage elasticity and therefore on the substitutional relationships between different skill groups. The larger the own-wage elasticity (in absolute terms) of the unqualified employees, the more effective would be a cut in their wages.

\section{Empirical Specification}

We have chosen a generalised Leontief cost function (Diewert, 1971), which belongs together with the translog (Christensen, Jorgenson and Lau, 1971 and 1973) to the two most commonly used flexible functional forms. These functions are linear second-order approximations to arbitrary cost or production functions. Although they cannot be derived from explicit production functions, they should be preferred to a Cobb-Douglas or CESfunctions, which restrict the substitution elasticities of the input factors to be equal to one or constant respectively. 
We have selected the following cost function: ${ }^{3}$

$$
\begin{array}{r}
C=Y \sum_{i} \sum_{j} \alpha_{i j} \sqrt{w_{i} w_{j}}+Y^{2} \sum_{\mathrm{i}} \beta_{i} w_{i}+K \sum_{i} \gamma_{i} w_{i}+P D \sum_{i} \delta_{P D i} w_{i}+P Z \sum_{i} \delta_{P Z i} w_{i}+u_{i} \\
\mathrm{i}, \mathrm{j}=1, \ldots, 6
\end{array}
$$

with $\alpha_{i j}=\alpha_{j i}$. It should be noted, that this specification is linear homogeneous in wages, a proportionate increase in wages rises costs by the same relative amount. On the other hand, neither constant returns-to-scale -i.e. $C\left(w_{i}, Y, K, P Z, P D\right)=Y * C\left(w_{i}, 1, K, P Z, P D\right)$ , nor homotheticity -i.e. $C\left(w_{i}, Y, K, P Z, P D\right)=h(Y)^{*} C\left(w_{i}, 1, K, P Z, P D\right)$ - are imposed directly and hold only as a special case. Moreover, the marginal cost of an additional unit of output is allowed to fall or rise, depending on the term $\sum_{i} \beta_{i} w_{i}$.

If all the parameters $\quad \alpha_{i j}$ for $i \neq j$ are nonnegative, the cost function will be concave (for all prices and output levels), which is required for optimisation (see Diewert, 1987). However, nonnegativity of the $\alpha_{i j}$ 's restricts all pairs of labour inputs to be substitutes.

For this reason we have not imposed the concavity restriction. Conditional labour demand is given by:

$$
N_{i}=Y \alpha_{i i}+Y \sum_{i \neq j} \alpha_{i j} \sqrt{\frac{w_{j}}{w_{i}}}+\beta_{i} Y^{2}+\gamma_{i} K+\delta_{P D i} P D+\delta_{P Z i} P Z+\varepsilon_{i} \quad \mathrm{i}, \mathrm{j}=1, \ldots, 6
$$

A demand system of the six (labour) input-output ratios contains all the relevant parameters, such that the cost function need not to be estimated. In particular, the effect of non-wage variables can easily be tested by adding these variables to each equation. In our case, the impact of innovations on the labour demand for the group $i$ are directly given by $\delta_{P D i}$ and $\delta_{P Z i}$. ${ }^{4} \mathrm{We}$ assume that $E\left(\varepsilon_{i}\right)=0$, but no homoscedasticity since it seems reasonable for the error variance to be positively correlated with the output level.

\footnotetext{
${ }^{3}$ Diewert and Wales (1987) suggest the inclusion of additional interaction terms such as $\mathrm{Y}^{* \mathrm{PD}}$ or $\mathrm{Y} * \mathrm{PZ}$, which proved to be insignificant when estimating the system of factor-output ratios.

${ }^{4}$ Conversely, the derivation of innovation effects is not as straightforward when estimating a translog system. In that case, the cost function, $C$, as well as the labour cost shares, $\mathrm{S}_{\mathrm{i}}$, must be estimated (with an additional loss of five degrees of freedom). The impact of innovations can be obtained by the formula $\left(\delta S_{i} / \delta \text { Innov }\right)^{*}\left(C / w_{i}\right)+(\delta \mathrm{C} / \delta$ Innov $) *\left(S_{i} / w_{i}\right)$.
} 
For this reason, most econometric studies in this context estimate a system of inputoutput ratios instead of the inputs themselves:

$$
\frac{N_{i}}{Y}=\alpha_{i i}+\sum_{i \neq j} \alpha_{i j} \sqrt{\frac{w_{j}}{w_{i}}}+\beta_{i} Y+\gamma_{i} \frac{K}{Y}+\delta_{P D i} \frac{P D}{Y}+\delta_{P Z i} \frac{P Z}{Y}+u_{i} \quad \mathrm{i}, \mathrm{j}=1, \ldots, 6
$$

If the error variance of the demand equations is proportionate to the squared output levels, $V\left(\varepsilon_{i}\right)=Y^{2} \sigma^{2}$, then $E\left(u_{i}\right)=0$ and $V\left(u_{i}\right)=\sigma^{2}$. In addition, we assume that the error terms between the labour inputs of one firm are correlated, but not those of different firms. The system of the six labour input-output ratios has been estimated by maximum likelihood for constrained linear systems in LIMDEP. From the estimated coefficients, one obtains the own-wage elasticities of the respective labour groups by the following formula

$$
\eta_{N_{i} w_{i}}=\frac{-.5 Y \sum_{j \neq i} \alpha_{i j} w_{j}^{.5}}{N_{i} w_{i}^{5}} \text {. }
$$

The cross wage elasticities are given by

$\eta_{N_{i} w_{j}}=\frac{.5 Y \alpha_{i j} w_{j}^{.5}}{N_{i} w_{i}^{.5}}$.

Finally, labour demand elasticities with respect to output and capital can be calculated as

$\eta_{N_{i} Y}=\frac{Y\left(\alpha_{i i}+\sum_{j \neq i} \alpha_{i j} w_{j}^{.5} w_{i}^{-.5}+2 Y \beta_{i}\right)}{N_{i}}$,

and

$\eta_{N_{i} K}=\frac{\gamma_{i} K}{N_{i}}$

When calculating the elasticities given in equations (6)-(9), the unknown coefficients $\alpha_{\mathrm{ij}}, \beta_{\mathrm{i}}, \gamma_{\mathrm{i}}$ have been replaced by their estimates $\hat{\alpha}_{\mathrm{ij}}, \hat{\beta}_{\mathrm{i}}, \hat{\gamma}_{\mathrm{i}}$ and the employment levels $\mathrm{N}_{\mathrm{i}}$ by their fitted values $\hat{N}_{i}=Y \hat{\alpha}_{i i}+Y \sum_{i \neq j} \hat{\alpha}_{i j} w_{j}^{.5} w_{i}^{-5}+\hat{\beta}_{i} Y^{2}+\hat{\gamma}_{i} K+\hat{\delta}_{P D i} P D+\hat{\delta}_{P Z i} P Z$. Obviously, the calculated elasticities are non-linear functions of the estimated parameters, rendering it very difficult to determine the exact standard errors for the 
former. ${ }^{5}$ We have used the Wald-procedure of $L I M D E P$, which calculates the standard errors of non-linear functions by the $\delta$-method.

Distinguishing between six different groups of employees, we are in a position to test whether or not they are separable into some aggregates (see Blackorby et al., 1978, for a comprehensive treatment of separability). These could be blue-collar and white collar workers or it might be conceivable that skilled and highly skilled employees can be aggregated. Referring to our framework, a subset of labour inputs, $S$, is separable if for any two skill groups of this subset the following holds:

$\frac{\partial}{\partial w_{k}}\left(\frac{\partial C(W, Y, K, P D, P Z) / \partial w_{i}}{\partial C(W, Y, K, P D, P Z) / \partial w_{j}}\right)=\frac{\partial}{\partial w_{k}}\left(\frac{N_{i}(W, Y, K, P D, P Z)}{N_{j}(W, Y, K, P D, P Z)}\right)=0 \quad \forall(\mathrm{i}, \mathrm{j}) \in \mathrm{S}, \forall \mathrm{k} \notin S$.

Thus, the cost function given in (3) is said to be separable with respect to the subset $S$, if the (constant-output) demand ratio for any two labour groups within this subset is independent of the wages of skill groups not in this subset. It should be noted, that this ratio depends on the level of output, given that we have not assumed homotheticity. Separability is of direct economic interest, since it implies the existence of multi-stage decision making. Also, it plays a crucial role for econometric analysis, allowing the use of aggregate data as well as to carry out estimations only with a subset of variables.

The separability condition in equation (10) can alternatively be written as

$N_{i} \frac{\partial N_{j}}{\partial w_{K}}-N_{j} \frac{\partial N_{i}}{\partial w_{K}}=0 \quad \forall(\mathrm{i}, \mathrm{j}) \in \mathrm{S}, \forall \mathrm{k} \notin S$,

or -applying the conditional labour demand equation (4)- as:

$N_{i} \frac{\alpha_{j k}}{\sqrt{w_{K} w_{j}}}-N_{j} \frac{\alpha_{i k}}{\sqrt{w_{K} w_{i}}}=0 \quad \forall(\mathrm{i}, \mathrm{j}) \in \mathrm{S}, \forall \mathrm{k} \notin S$.

A special case arises if $\alpha_{j k}=\alpha_{i k}=0$, i.e. labour demand for both, inputs $i$ and $j$, is not affected by the wage of skill group $k$. Symmetry of the second-order coefficients then implies $\alpha_{k j}=\alpha_{k i}=0$, therefore in this special case the separability relation is symmetric ( $\mathrm{S}$ is separable from $\mathrm{R} \leftrightarrow \mathrm{R}$ is separable from $\mathrm{S}$ ). On the other hand, if $\alpha_{i k} \neq 0$ and

\footnotetext{
${ }^{5}$ Using the observed actual values $\mathrm{N}_{\mathrm{i}}$ does not solve this problem, since -by definition- they are stochastic as well.
} 
$\alpha_{j k} \neq 0$, we substitute equation (4) into equation (11), which yields after rearranging the separability restriction

$$
\begin{aligned}
& Y \sum_{m}\left(\alpha_{m i} \alpha_{j k}-\alpha_{m j} \alpha_{i k}\right) w_{m}^{5}\left(w_{i} w_{j} w_{k}\right)^{-5}+Y^{2}\left(\beta_{i} \frac{\alpha_{j k}}{\sqrt{w_{K} w_{j}}}-\beta_{j} \frac{\alpha_{i k}}{\sqrt{w_{K} w_{i}}}\right) \\
& +K\left(\gamma_{i} \frac{\alpha_{j k}}{\sqrt{w_{K} w_{j}}}-\gamma_{j} \frac{\alpha_{i k}}{\sqrt{w_{K} w_{i}}}\right)+P D\left(\delta_{P D_{i}} \frac{\alpha_{j k}}{\sqrt{w_{K} w_{j}}}-\delta_{P D_{j}} \frac{\alpha_{i k}}{\sqrt{w_{K} w_{i}}}\right) \\
& +P Z\left(\delta_{P Z_{i}} \frac{\alpha_{j k}}{\sqrt{w_{K} w_{j}}}-\delta_{P Z_{j}} \frac{\alpha_{i k}}{\sqrt{w_{K} w_{i}}}\right)=0
\end{aligned}
$$

Except for the first term the separability conditions are not independent of the wages, i.e. the conditions cannot be globally satisfied. Nevertheless, in addition to the linear restrictions $\alpha_{k j}=\alpha_{k i}=0$, we have also tested for the more general non-linear case represented by equation (12), where we have used the sample means of $N_{i}$ and $N_{j}$. If the condition will be rejected at the sample means, obviously separability will be rejected globally. Unfortunately, if the non-linear restriction will be accepted at one point, it does not have much statistical power. Finally, it should be mentioned that separability tests impose -at least when the functional forms are viewed as exact and not as approximations- a restrictive structure on the production technology. ${ }^{6}$

In section 4, we will present and discuss the effect of innovations and wages on the demand for different skill groups as well as capital- and output-elasticities of labour demand, which we estimated for the production industry of West Germany for the year 1995. We will also report separability tests where we have independently tested whether or not each of the following four subsets can be aggregated: the three groups of bluecollar workers, the three groups of white collar workers, skilled/highly skilled blue collar workers and skilled/highly skilled white collar workers. First, however, we will describe the used employer-employee data-set in the next section. 


\section{Data Description}

For the system-estimation of the input-output ratios given in section 2, we need information on the number of employees as well as on wages for the six skill groups, on value added, capital stock and innovations. Information about value added, capital stock and innovations can be obtained from the IAB-establishment panel (see Bellmann 1997, Bellmann et al. 1999), a yearly survey of more than 4000 firms in West Germany since 1993 (and of additional 5000 firms in East Germany since 1996) carried out by Infratest Burke Sozialforschung. The number of employees and wages for the different skill groups are given in the historic files of the employment statistics register (see Bender et al. 1996)

Since the employment statistics contain a firm identification number for each employee, they can be matched with the IAB-establishment panel. ${ }^{7}$ This yields to an employeremployee data-set for Germany comprising information on all employees obliged to social-security payments and belonging to those firms which are included in the establishment panel. So far, only the historic files of 1995 are available for empirical research, restricting our analysis to this year.

There are several alternatives for an aggregation of employees into different qualification groups. One possibility follows directly from the employment statistics where workers are classified according to their occupational status. The employment statistics contain three categories for blue collar workers and one category for white collar workers. However, the categorisation is not always distinct, since a master craftsmen ${ }^{8}$, for example, could be a blue-collar or a white-collar worker. For this reason, and also to allow a differentiation within white-collar workers, we have used a classification of occupation (see Blossfeld 1989), where blue-collar workers have been stratified into non-qualified, qualified and technicians/engineers and white collar workers into simple services,

\footnotetext{
${ }^{6}$ The linear separability conditions imply that the subsets are generalised Leontief cost functions themselves whereas for the non-linear conditions the subsets are CES-functions (see Denny/Fuss, 1977 or Blackorby et al.,1977).

${ }^{7}$ A survey of matched employer-employee data-sets on international basis can be found in Abowd and Kramarz (1999), Haltiwanger (1998) summarises the results of a large international workshop on this topic.
} 
qualified services and (semi-) professionals/managers. ${ }^{9}$ Wages for each of the six skill groups at the firm level have been obtained by the median wage of all employees within one group and one firm ${ }^{10}$.

The employment statistics offer a high quality of wage data. A disadvantage of this data, however, is that wages are censored at the limit up to which social security payments are compulsory, i.e. anybody with an actual income above the limit has a reported income at his limit. Those firms with median wages of all skill groups below the ceiling are obviously not affected (in contrast to average wages), but for about two thirds of all firms the median wage of the highly skilled white collar workers is identical to the upper limit.

In general, part-time employees should be included as a separate input factor. Only if full-time employees as a group can be separated from part-time employees, it is correct to neglect the latter. For part-time employees, however, data on wages is very imprecise, thus they have not been included into the analysis. The problem has been at least mitigated by dropping those firms with a high percentage of part-time employees (more than 33\%). ${ }^{11}$ For the same reasons, firms where the percentage of apprentices within all employees obliged to social security payments exceeds $33 \%$ have been excluded.

The analysis focuses on the manufacturing and the construction industry in West Germany; agriculture, mining, energy as well as trade, services and public administration have not been included. The latter clearly differ from the manufacturing and the construction industry regarding the production process and technology. So pooling all sectors into one regression sample may bias the results. In addition, it should be expected that firms with no or just one employee in at least one of the six qualification groups exhibit different substitution possibilities. Therefore only those firms with at least

\footnotetext{
${ }^{8}$ Many craft trades, such as carpentry, vehicle repair and hairdressing can be carried out only by or under the supervision of a master craftsman.

${ }^{9}$ For ease of notation and comparability, we will speak in the following of unskilled, skilled and highly skilled blue and white collar workers respectively.

${ }^{10}$ The median wage has been preferred over the average wage, since the latter is more sensitive to outliers.

${ }^{11}$ This implies that for a firm with 12 employees, say, (which is the minimal firm size given the requirement that each of the 6 skill groups consist of at least 2 employees) to fulfill the requirement not more than 4 employees are allowed to work part-time. Alternative limits would be more than $25 \%$ (not more than three part-timers) or $50 \%$ (not more than 6 part-timers),
} 
two employees in all qualification groups have been selected. Since for about one fourth of all firms no information on intermediate inputs is available, we have used sales instead of value added as proxy for output. The capital stock has been approximated by investments of the year 1995. It might have been reasonable to consider investment expenditures in 1993 and 1994 as well, but this would lead in fact to a further reduction in the sample size. Finally, 600 firms remain for the econometric analysis.

Only quantitative data about product and process innovations exist, i.e. whether a firm has implemented a product or process innovation in the last year.

Table 1: Product and process innovations in the matched data set

\begin{tabular}{c|c|c|c} 
& \multicolumn{2}{|c|}{$\begin{array}{c}\text { Process- } \\
\text { innovation }\end{array}$} & \\
\hline $\begin{array}{c}\text { Product- } \\
\text { innovation }\end{array}$ & No & Yes & Sum \\
\hline No & 69 & 321 & 390 \\
\hline Yes & 45 & 165 & 210 \\
\hline Sum & 104 & 486 & 600
\end{tabular}

As can be seen from table1, more than a quarter of all firms introduced product as well as process innovations, while only about ten percent did not innovate. The number of firms reporting only process innovations ( $54 \%$ of all firms) is much higher than those with only product innovations (about $8 \%$ of all firms). Summary statistics of all other variables are reported in the appendix. 


\section{Estimation results}

Table 2 contains the estimated innovation coefficients from equation 5 . We have estimated four specifications: incorporating only a product innovation dummy (version 1), only a process innovation dummy (version 2), product and process innovation dummies (version 3), and finally a dummy indicating whether a firm has implemented a process and/or a product innovation (version 4). When including two innovation dummies (version 3), product innovations are insignificant for each of the six groups, whereas process innovations show a positive and significant coefficient for all but the highly skilled blue collar workers.

Table 2: Estimated relative change of conditional labour demand $\left(d N_{i} / N_{i}\right)$ for different skill groups due to innovations

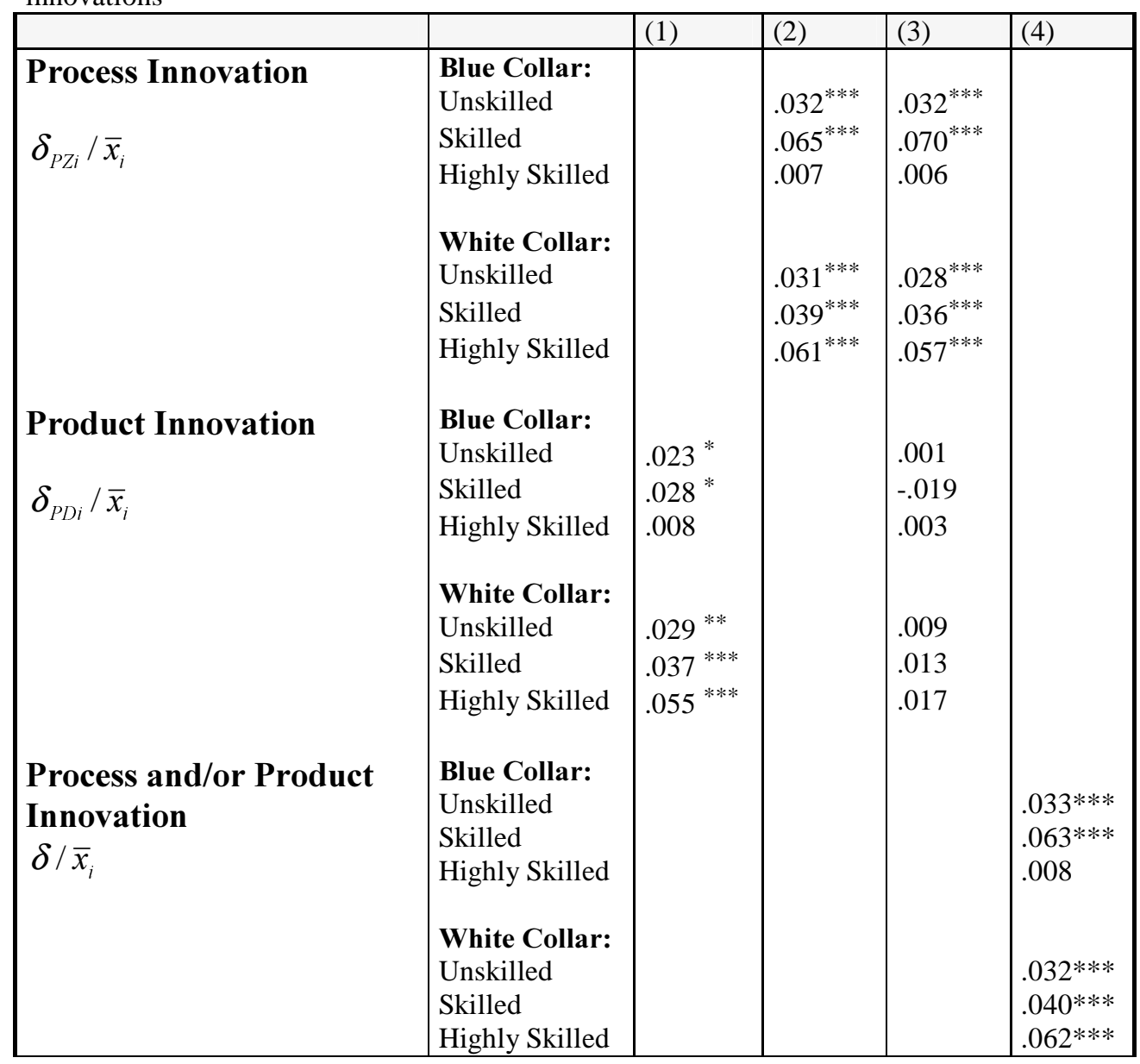

$* / * * / * * *$ denotes significance at the $10 / 5 / 1 \%$ level

Versions 1 and 2, however, including only one of the respective innovation dummies, show a very similar pattern for product and process innovations. Due to the 
small share of firms, which have implemented solely process innovations (8\%), it is not possible to disentangle the impact of both innovation types. For this reason, in the following we will refer to version 4 where only one dummy is included indicating whether a firm has implemented any of the two innovation types. First of all, innovations have a positive impact on conditional labour demand aggregated over the six groups, with a weighted average for the relative change in aggregate labour demand of $3.7 \%$ (with an asymptotic t-statistic of 8.15 ). Only the group of highly skilled blue collar workers (technicians, engineers) exhibits an insignificant coefficient. This result may look initially puzzling, as one would normally expect the most increasing demand for qualified employees rises most (or, equivalently, least decreasing) after the implementation of innovations. An explanation of our result can be found in the context of industrial sociology, where researchers have pointed towards three main problems facing the demand for highly skilled blue collar workers. First, the introduction of new organisational structures has dramatically reduce the demand for this group. Secondly, an increasing number of firms may hire applicants with a degree from a secondary technical college ${ }^{12}$ for these jobs (who belong to the group of highly-skilled white-collar workers). Finally, they mention a labour hoarding of highly skilled blue collar workers -particularly within large firms- in the past (see for example, Drexel 1993). These phenomenen are more severe regarding large firms, as is undermined by a study of Plicht (1999), and are thus inherent to our sample, which is biased towards large firms ${ }^{13}$. On the other hand, the propensity to innovate rises with firm size, therefore perfectly matching the obtained result of an insignificant impact of innovations on labour demand for highly skilled blue collar workers.

With respect to white collar workers, the hypothesis of a positive correlation between qualification and innovations is confirmed. The coefficient for highly skilled white collar workers is almost double than the one for the unskilled white collar workers and about 1.5 times the coefficient for skilled white collar workers. ${ }^{14}$ Between unskilled blue-collar workers and skilled blue collar workers the qualification-innovation hypothesis holds as well, with a coefficient almost double for the latter group than for the former. ${ }^{15}$ Finally, comparing blue-collar and white collar workers, the unskilled exhibit statistically identical

\footnotetext{
12 With degree as Diplom-Ingenieur (FH), for example.

${ }^{13}$ First, large firms are overrepresented in the IAB establishment panel. Second, we restricted the sample to those firms which have at least 2 employees in each of the six qualification groups.

${ }^{14}$ Both correlations are significant at the $1 \%$-level.
} 
coefficients for both groups, whereas the impact of innovations on skilled employees is 1.5 times higher for blue collar employees if compared to skilled white collar workers. All effects are calculated for conditional labour demand, assuming constant output. Therefore, the coefficients do not account for possible scale effects.

The estimated wage elasticities are reported in Table 3. The own-wage elasticities for unskilled and skilled blue collar workers as well as for skilled white collar workers exhibit the expected negative sign (although it is significant only for the latter). The positive own-wage elasticities for unskilled white collar workers is unexpected and we have no reasonable explanation for this result. Comparing skilled and highly-skilled employees, the hypothesis that the own-wage elasticity decreases with skill is confirmed (Hamermesh, 1993), whereas it does not hold when comparing the unskilled with the skilled.

Table 3: Wage elasticities of labour demand for different skill groups (calculated at means of fitted values)

\begin{tabular}{|c|c|c|c|c|c|c|}
\hline & \multicolumn{3}{|c|}{ Wages of Blue Collar Workers } & \multicolumn{3}{|c|}{ Wages of White Collar Workers } \\
\hline $\begin{array}{l}\text { Labour } \\
\text { Demand } \\
\text { Elasticities }\end{array}$ & Unskilled & Skilled & Highly skilled & unskilled & Skilled & Highly Skilled \\
\hline Blue Collar & & & & & & \\
\hline -unskilled & -0.4 & 0.4 & 0.1 & -0.1 & -0.05 & -0.05 \\
\hline -skilled & 0.7 & -0.5 & -0.2 & -0.03 & -0.05 & 0.04 \\
\hline -highly skilled & $0.3^{*}$ & -0.2 & 0.2 & $-0.2^{*}$ & 0.1 & $-0.2^{\star \star \star}$ \\
\hline White Collar & & & & & & \\
\hline -unskilled & $-0.5^{\star \star \star}$ & $-0.1^{\star \star \star}$ & $-0.6^{\star \star \star}$ & $0.4^{\star \star \star}$ & $0.4^{\star \star \star}$ & $0.4^{\star \star \star}$ \\
\hline -skilled & $-0.1^{\star *}$ & -0.1 & $0.1^{\star * \star}$ & $0.3^{* \star *}$ & $-0.3^{\star \star \star}$ & $0.1^{* * *}$ \\
\hline -highly skilled & $-0.5^{\star * *}$ & $0.2^{\star \star \star}$ & $-0.8^{* \star *}$ & $0.8^{\star \star \star}$ & $0.3^{* *}$ & $-0.03^{\star * \star}$ \\
\hline
\end{tabular}

${ }^{*} /{ }^{* * * *}$ denotes significance at the $10 / 5 / 1 \%$ level, where the standard errors have been calculated with the Wald-Procedure within LIMDEP.

The group of unskilled employees are substitutes with skilled and highly skilled employees, although -again- this relationship is not significant for blue-collar workers.

\footnotetext{
${ }^{15}$ Statistically significant at the $5 \%$-level.
} 
Unskilled, skilled and highly-skilled blue collar workers are complements to the respective group of the white-collar workers.

Labour demand elasticities with respect to output, $\eta_{1 Y}-\eta_{6 Y}$, and with respect to capital, $\eta_{1 K}-\eta_{6 K}$ are listed in the appendix. The output elasticities lie all in the fairly small range between 0.72 and 0.89 and, more importantly, the hypothesis that all estimated values are equal to 1 is rejected at the 1\%-level, implying increasing returnsto-scale. If $\eta_{1 Y}=\ldots=\eta_{6 Y}$, the production technology is homothetic and the cost shares remain constant after a change in scale (homotheticity follows from constant returns to scale, but not vice versa). However, homotheticity is rejected as well, with the share of highly skilled blue collar workers rising after an increase in output. The hypothesis of a capital-skill complementarity cannot be confirmed, that is labour demand elasticity with respect to capital is not rising with skill, neither for blue collar workers nor for white collar workers. However, the approximation of capital by last year's investment may not be adequate; thus, the estimated capital elasticities should be interpreted with care.

We finish this section by reporting the separability tests, where we have tested (independently) the existence of four alternative subaggregates: blue collar workers, white collar workers, skilled and highly skilled blue collar workers, skilled and highly skilled white collar workers. As can be seen from the table below, the linear restrictions $\left(\alpha_{j k}=\alpha_{i k}=0\right)$ have to be rejected for all four subsets. The non-linear conditions given in equation (12) have been tested at the averages of the fitted values of $N_{i}$ and $N_{j}$. Separability of white-collar workers from blue-collar workers (456-123), skilled and highly skilled white-collar workers from the other four groups (56-1234) as well as blue-collar workers from white-collar workers (123-456) is not consistent with our data. Contrary, the existence of an aggregate index for skilled and highly-skilled blue collar workers is not clear-cut, it would be accepted at the 10\%-level. However, as we have noted in section 3 , acceptance at one point does not imply global separability. 
Table 4: Test Statistics of Separability Restrictions

\begin{tabular}{|l|l|l|}
\hline & Wald-Statistic & P-value \\
\hline Linear Separability & & \\
$\mathbf{1 2 3 - 4 5 6}$ & 42.36 & {$[.000]$} \\
$\mathbf{2 3 - 1 4 5 6}$ & 38.33 & {$[.000]$} \\
$\mathbf{4 5 6 - 1 2 3}$ & 42.36 & {$[.000]$} \\
$\mathbf{5 6 - 1 2 3 4}$ & 39.78 & {$[.000]$} \\
Non-linear Separability & & \\
Restrictions & & \\
$\mathbf{1 2 3 - 4 5 6}$ & 8.92 & {$[.178]$} \\
$\mathbf{2 3 - 1 4 5 6}$ & 7.89 & {$[.096]$} \\
$\mathbf{4 5 6 - 1 2 3}$ & 325.29 & {$[.000]$} \\
$\mathbf{5 6 - 1 2 3 4}$ & 243.59 & {$[.000]$} \\
\hline
\end{tabular}

Test whether first set is separable from the second, where

$1=$ unskilled blue collar worker

$2=$ skilled blue collar worker

3 =highly skilled blue collar worker

4=unskilled white collar worker

$5=$ skilled white collar worker

6=highly skilled white collar worker 


\section{Conclusions}

This paper has investigated the relationship between innovations, wages and heterogeneous demand of labour. Our analysis has been based on a matched data of the IAB-establishment panel and the historic files of the employment statistics register. Classifying the labour input into six groups (blue and white collar workers stratified into unskilled, skilled and highly-skilled employees), a labour share system derived from a generalised Leontief cost function has been estimated for the West German production industry of 1995 .

From a theoretical point of view, the effect of product and process innovations cannot be predicted unambiguously. Since product and process innovations are often implemented simultaneously, it was not possible to identify the effects of both types separately. Product and/or process innovations exhibited a positive impact on all conditional labour demands except for the highly skilled blue collar workers. We have argued that this result does not necessarily imply that this group is less complementary to innovations than others, but may reflect different phenomenen (labour hoarding of highly skilled blue collar workers in the past). Between white collar workers as well as between unskilled and skilled blue collar workers, we find that the higher the skill level of employees, the larger the positive effect of innovations on labour demand of the respective group.

If substitution possibilities between different skill groups exist, then a change in their relative wages would alter their demand. Therefore, our finding of a substitutional relationship between unskilled and skilled/highly-skilled employees, i.e. a positive crosswage elasticity, implies that more flexible wages of the unskilled could reduce unemployment of this group. Separability between blue-collar workers and white-collar workers has been rejected, whereas we have found weak evidence that skilled and highly skilled blue-collar workers can be aggregated.

The preceding analysis is only a first step in exploring a new data-set. Once information of additional years from the matched employer-employee data is available, further insights into the relationship between innovations, wages and labour demand can be gained by applying panel analysis techniques. 


\section{References}

Abowd, J. M. ; Kramarz, F. (1999): The analysis of labor markets using matched employer - employee data, in: Ashenfelter, H.; Card, D. (eds.), Handbook of labor economics, Amsterdam.

Bellmann, L. (1997): Das IAB-Betriebspanel. Sonderhefte des Allgemeinen Statistischen Archivs, 80, 169-182.

Bellmann, L.; Conrads, R.; Hilpert, M.; Huber, A.; Kistler, E.; Kölling, A. (1999): Codebuch zum IAB-Betriebspanel. Stadtbergen, Nürnberg.

Bellmann, L.; Bender, S.; Schank,T. (1999): Flexibilität der Qualifikationsstruktur aus betrieblicher Sicht: Substitutionalität oder Komplementarität, Jahrbücher für Nationalökonomie und Statistik, 219/1+2, 109-126.

Bender, S.; Hilzendegen, J.; Rohwer, G; Rudolph, H. (1996): Die IAB-Beschäftigtenstichprobe 1975 - 1990. Eine praktische Einführung; Beiträge zur Arbeitsmarktund Berufsforschung 197.

Blackorby, C.; Primont, D; Russel, R. (1977): On Testing Separability Restrictions with Flexible Functional Forms, Journal of Econometrics, 5, 195-200.

Blackorby, C.; Primont, D; Russel, R. (1978): Duality, Separability, and Functional Structure: Theory and Economic Applications, North-Holland.

Blechinger, D.; Kleinknecht, A.; Licht,G.; Pfeiffer, F. (1994): The Impact of Innovation on Employment in Europe - An Analysis Using CIS Data, Report for the European Commission.

Blechinger, D.; Pfeiffer, F. (1999): Qualifikation, Beschäftigung und technischer Fortschritt. Jahrbücher für Nationalökonomie und Statistik, 218/1+2, 128-146.

Blossfeld, H. P. (1989): Kohortendifferenzierung und Karriereprozeß - Eine Längsschnittstudie über die Veränderung der Bildungs- und Berufschancen im Lebensverlaufs, Frankfurt/M., New York.

Christensen, L.R; Jorgenson, D. W; Lau, L.J.(1971): Conjugate Duality and the Transcendental Logarithmic Production Function (abstract), Econometrica 39, 255-56.

Christensen, L.R, Jorgenson, D. W., und Lau, L.J.(1973):Transcendental Logarithmic Production Frontiers, Review of Economics and Statistics 55, 28-45.

Denny, M.; Fuss, M. (1977): The Use of Approximation Analysis to Test for Separability and the Existence of Consistent Aggregates, 67.1, 404-418.

Diewert, W.E. (1971): An Application of the Shepard Duality Theorem: A Generalized Leontief Production Function, Journal of Political Economy, 79, 481-507. 
Diewert, W. E.; Wales, T.J. (1987): Flexible Functional Forms and Global Curvature Conditions, Econometrica, Vol. 55, 43-68.

Drexel, I. (1993): Das Ende des Facharbeiteraufstieges? Frankfurt/M., New York.

Fitzenberger, B; Franz, W. (1998): Flexibilität der qualifikatorischen Lohnstruktur und Lastverteilung der Arbeitslosigkeit: Eine ökonometrische Analyse für Westdeutschland, in: Gahlen, B.; Hesse,H.; Ramser, H.J. (eds.), Verteilungsprobleme der Gegenwart. Diagnose und Therapie, Tübingen, 47-79

Flaig, G.;Rottmann, H. (1999): Direkte und indirekte Beschäftigungseffekte von Innovationen. Eine empirische Paneldatenanalyse für Unternehmen des westdeutschen Verarbeitenden Gewerbes, in: Bellmann, L.; Steiner, V. (eds.): Lohnstruktur, Beschäftigung und Beschäftigungsdynamik; Beiträge zur Arbeitsmarkt- und Berufsforschung, 229, 149-166.

Haltiwanger, J. (1998): Creating employer-employee data sets. Monthly Labor Review $121(7), 49-51$.

Hamermesh, D. S. (1993): Labor Demand, Princeton N.J.

König, H.; Buscher, H.; Licht, G. (1995): Employment, Investment and Innovation at the Firm Level. In: OEDC (ed.), The OECD Jobs Study - Investment, Productivity and Employment, Paris, 67- 80.

Plicht, H. (1999): Entwicklung im Bereich der traditionellen Aufstiegspositionen für gewerblich-technische Fachkräfte (Meister-/Technikerpositionen): Substitution und Angebotsentwicklung, Bericht für den gemeinsamen Ausschuß für Arbeitsmarkt- und Berufsforschung des Vorstandes und des Verwaltungsrates der Bundesanstalt für Arbeit.

Reinberg, A.; Rauch, A. (1999): Qualifikation und Beschäftigung: Bildung verteilt Chancen am Arbeitsmarkt. IAB-Materialien, Ausgabe 99/2.

Riphan, R.; Zimmermann, K. (1999): Schaffung von Arbeitsplätzen für Geringqualifizierte. Gutachterliche Stellungnahme im Auftrag des Bundesministeriums für Arbeit und Sozialordnung. IZA Bonn.

Rottmann, H.; Ruschinski, M. (1998): The Labour Demand and the Innovation Behaviour of Firms. Jahrbücher für Nationalökonomie und Statistik, 217/6, 741-752.

Smolny, W.; Schneeweis, Th., (1999): Innovation, Wachstum und Beschäftigung. Jahrbücher für Nationalökonomie und Statistik, 218/3+4, 453-472.

Zimmermann, K.F. (1991): Technologieentwicklung und Beschäftigung: Endogene Produkt- und Prozeßinnovation und die Rolle von Lohnkosten und Nachfrage, in: Scherf, H. (ed.), Beschäftigungsprobleme hochentwickelter Volkswirtschaften. Berlin, 131-143. 
Appendix

Table A1: Conditional labour demand elasticities, calculated with fitted values at sample means, for version (4) (one dummy which comprises product and process innovations)

\begin{tabular}{|c|c|c|c|c|}
\hline & Coefficient & Standard Error & $\mathbf{z}=\mid \mathrm{b} /$ St.Er. $\mid$ & $\mathbf{P}[|\mathbf{Z}|>\mathbf{z}]$ \\
\hline$\eta 11$ & -.3752809025 & .28948904 & -1.296 & .1949 \\
\hline$\eta 12$ & .4476470620 & .28389643 & 1.577 & .1148 \\
\hline$\eta 13$ & .1438975140 & .29046353 & .495 & .6203 \\
\hline$\eta 14$ & -.1179293660 & .10061249 & -1.172 & .2412 \\
\hline$\eta 15$ & $-.4943041716 \mathrm{E}-01$ & .12341464 & -.401 & .6888 \\
\hline$\eta 16$ & $-.4890389023 \mathrm{E}-01$ & .10667568 & -.458 & .6466 \\
\hline$\eta 21$ & .7099113134 & .55999734 & 1.268 & .2049 \\
\hline$\eta 22$ & -.4964115321 & .71759884 & -.692 & .4891 \\
\hline$\eta 23$ & -.1734024591 & .13017582 & -1.332 & .1828 \\
\hline$\eta 24$ & $-.32239748 \mathrm{E}-01$ & .34827400 & -.093 & .9262 \\
\hline$\eta 25$ & $-.45585405 \mathrm{E}-01$ & .19813346 & -.230 & .8180 \\
\hline$\eta 26$ & $.377278313 \mathrm{E}-01$ & $.63136770 \mathrm{E}-01$ & .598 & .5501 \\
\hline$\eta 31$ & .2501082841 & .13381688 & 1.869 & .0616 \\
\hline$\eta 32$ & -.1900184142 & .16130734 & -1.178 & .2388 \\
\hline$\eta 33$ & .2314671670 & .22695839 & 1.020 & .3078 \\
\hline$\eta 34$ & -.2272286686 & .10652559 & -2.133 & .0329 \\
\hline$\eta 35$ & $.8920896636 \mathrm{E}-01$ & $.69333044 \mathrm{E}-01$ & 1.287 & .1982 \\
\hline$\eta 36$ & -.1535373346 & $.33611405 \mathrm{E}-01$ & -4.568 & .0000 \\
\hline$\eta 41$ & -.5380929786 & $.48739057 \mathrm{E}-01$ & -11.040 & .0000 \\
\hline$\eta 42$ & $-.8353088635 \mathrm{E}-01$ & $.30418433 \mathrm{E}-01$ & -2.746 & .0060 \\
\hline$\eta 43$ & -.5769090326 & $.37000812 \mathrm{E}-01$ & -15.592 & .0000 \\
\hline$\eta 44$ & .3935946101 & $.34173092 \mathrm{E}-01$ & 11.518 & .0000 \\
\hline$\eta 45$ & .4278927939 & $.32651007 \mathrm{E}-01$ & 13.105 & .0000 \\
\hline$\eta 46$ & .3653941809 & $.24706673 \mathrm{E}-01$ & 14.789 & .0000 \\
\hline$\eta 51$ & -.1311755627 & $.52425660 \mathrm{E}-01$ & -2.502 & .0123 \\
\hline$\eta 52$ & $-.76294918 \mathrm{E}-01$ & $.55136654 \mathrm{E}-01$ & -1.384 & .1664 \\
\hline$\eta 53$ & .1362443342 & $.38023770 \mathrm{E}-01$ & 3.583 & .0003 \\
\hline$\eta 54$ & .3049959968 & $.39391215 \mathrm{E}-01$ & 7.743 & .0000 \\
\hline$\eta 55$ & -.2745187153 & $.36980684 \mathrm{E}-01$ & -7.423 & .0000 \\
\hline$\eta 56$ & $.8831079100 \mathrm{E}-01$ & $.12931606 \mathrm{E}-01$ & 6.829 & .0000 \\
\hline$\eta 61$ & -.4676404467 & $.29131131 \mathrm{E}-01$ & -16.053 & .0000 \\
\hline$\eta 62$ & .2274950982 & $.14228124 \mathrm{E}-01$ & 15.989 & .0000 \\
\hline$\eta 63$ & -.8447181740 & $.52323897 \mathrm{E}-01$ & -16.144 & .0000 \\
\hline$\eta 64$ & .7919415818 & $.49218025 \mathrm{E}-01$ & 16.090 & .0000 \\
\hline$\eta 65$ & .3181382090 & $.20168723 \mathrm{E}-01$ & 15.774 & .0000 \\
\hline$\eta 66$ & $-.2521626830 \mathrm{E}-01$ & $.25529447 \mathrm{E}-02$ & -9.877 & .0000 \\
\hline$\eta \mathbf{1 K}$ & .1397253447 & $.57802872 \mathrm{E}-01$ & 2.417 & .0156 \\
\hline$\eta 2 K$ & $.6240474583 \mathrm{E}-01$ & $.60616896 \mathrm{E}-01$ & 1.029 & .3032 \\
\hline$\eta 3 K$ & $.4015860513 \mathrm{E}-01$ & $.36111317 \mathrm{E}-01$ & 1.112 & .2661 \\
\hline$\eta \mathbf{4 K}$ & .1246253405 & $.36100637 \mathrm{E}-01$ & 3.452 & .0006 \\
\hline$\eta 5 K$ & $.671719221 \mathrm{E}-01$ & $.26167516 \mathrm{E}-01$ & 2.567 & .0103 \\
\hline
\end{tabular}




\begin{tabular}{|l|l|l|l|l|}
$\eta \mathbf{6 K}$ & $.5650467698 \mathrm{E}-01$ & $.48189366 \mathrm{E}-01$ & 1.173 & .2410 \\
$\eta \mathbf{1 y}$ & .7094616824 & .10787577 & 6.577 & .0000 \\
$\eta \mathbf{2 y}$ & .7240715435 & .23382640 & 3.097 & .0020 \\
$\eta \mathbf{3 y}$ & .8914184581 & $.44903307 \mathrm{E}-01$ & 19.852 & .0000 \\
$\eta \mathbf{4 y}$ & .7324349843 & $.38460404 \mathrm{E}-01$ & 19.044 & .0000 \\
$\eta \mathbf{5 y}$ & .7745388865 & $.27893773 \mathrm{E}-01$ & 27.767 & .0000 \\
$\eta \mathbf{6 y}$ & .7609017728 & $.46722873 \mathrm{E}-01$ & 16.285 & .0000 \\
\hline
\end{tabular}

$\eta_{i j}=$ labour demand elasticity of skill group $i$ with respect to the wage of group $j$

(at constant output)

$\eta i K=$ labour demand elasticity of skill group $i$ with respect to the capital stock

$\eta$ iy=labour demand elasticity of skill group $i$ with respect to output

where $i, j=1, \ldots, 6$ and

$1=$ unskilled blue collar worker

$2=$ skilled blue collar worker

$\mathbf{3}=$ highly skilled blue collar worker

4=unskilled white collar worker

$\mathbf{5}=$ skilled white collar worker

$6=$ highly skilled white collar worker 
Table A2: Descriptive Statistics

Number of firms: 600

\begin{tabular}{|c|c|c|c|c|}
\hline Variable & Average & Std.Dev. & Min. & Max. \\
\hline \multicolumn{5}{|l|}{ Blue Collar Workers } \\
\hline Number & 431.80 & 653.91 & 2 & 7104 \\
\hline Nonqualified & & & & \\
\hline Median daily wage & 148.26 & 27.55 & 37.64 & 256.44 \\
\hline Nonqualified & & & & \\
\hline Number & 238.96 & 435.59 & 2 & 5656 \\
\hline Qualified & & & & \\
\hline Median daily wage & 162.89 & 22.31 & 72.94 & 254.77 \\
\hline Qualified & & & & \\
\hline Number & 198.43 & 442.60 & 2 & 8090 \\
\hline Technicians, Engineers & & & & \\
\hline $\begin{array}{l}\text { Median daily wage } \\
\text { Technicians, Engineers }\end{array}$ & 227.12 & 27.19 & 134.07 & 256.89 \\
\hline $\begin{array}{l}\text { Labour cost share } \\
\text { Nonqualified }\end{array}$ & .3458119 & .1934391 & .0014782 & .8216773 \\
\hline $\begin{array}{l}\text { Labour cost share } \\
\text { Qualified }\end{array}$ & .2005516 & .1332078 & .0013799 & .7238942 \\
\hline $\begin{array}{l}\text { Labour cost share } \\
\text { Technicians, Engineers }\end{array}$ & .1954706 & .1231964 & .0029253 & .7383685 \\
\hline White Collar Workers & & & & \\
\hline $\begin{array}{l}\text { Number Simple } \\
\text { Administrative }\end{array}$ & 111.03 & 219.98 & 2 & 3043 \\
\hline $\begin{array}{l}\text { Median daily wage } \\
\text { Simple Administrative }\end{array}$ & 153.12 & 30.16 & 48 & 256.44 \\
\hline $\begin{array}{l}\text { Number Qualified } \\
\text { Services }\end{array}$ & 141.3 & 273.42 & 2 & 4848 \\
\hline $\begin{array}{l}\text { Median daily wage } \\
\text { Qualified Services }\end{array}$ & 181.40 & 33.53 & 47.27 & 256.58 \\
\hline $\begin{array}{l}\text { Number } \\
\text { (semi-)Professionals, } \\
\text { Managers }\end{array}$ & 32.96 & 92.21 & 2 & 1561 \\
\hline $\begin{array}{l}\text { Median daily wage } \\
\text { (semi-) Professionals, } \\
\text { Managers }\end{array}$ & 246.97 & 25.15 & 34.67 & 257.14 \\
\hline $\begin{array}{l}\text { Labour Cost share } \\
\text { Simple Administrative }\end{array}$ & .0858096 & .0756487 & .0063988 & .6064289 \\
\hline $\begin{array}{l}\text { Labour cost share } \\
\text { Qualified Service }\end{array}$ & .1341953 & .0705666 & .0073651 & .6543629 \\
\hline $\begin{array}{l}\text { Labour cost share } \\
\text { (semi-) Professionals, } \\
\text { Managers }\end{array}$ & .038161 & .0324071 & .0017003 & .2261508 \\
\hline Investment & $2.17 \mathrm{e}+07$ & $6.29 e+07$ & 50000 & $1.00 \mathrm{e}+09$ \\
\hline Sales & $4.61 \mathrm{e}+08$ & $1.05 \mathrm{e}+09$ & $6.00 \mathrm{e}+06$ & $1.71 \mathrm{e}+10$ \\
\hline $\begin{array}{l}\text { Number of all } \\
\text { employees } \\
\text { Within firm }\end{array}$ & 1343.00 & 2724.95 & 31 & 51155 \\
\hline
\end{tabular}


Number of all

1407.75

2868.88

31

51155

employees for

Innovating firms

$(n=531)$

Number of all

844.74

987.29

104

6539

employees for

non-innovating firms

$(n=69)$

Distribution of firms over industries

\begin{tabular}{|l|l|l|}
\hline & Number & $\begin{array}{l}\text { Percen- } \\
\text { tage }\end{array}$ \\
\hline Production Goods Ind. & 177 & $.295 \%$ \\
\hline Investment Ind. & 309 & $.515 \%$ \\
\hline Consumption Goods Ind. & 97 & $.162 \%$ \\
\hline Construction Ind. & 17 & $.028 \%$ \\
\hline & & \\
\hline Total & 600 & $100 \%$ \\
\hline
\end{tabular}

